\title{
DIET OF A CRYPTIC BUT WIDESPREAD INVADER, THE ORIENTAL WEATHERFISH (MISGURNUS ANGUILLICAUDATUS) IN IDAHO, USA
}

\author{
Alexander N. Urquhart ${ }^{1,2}$ and Peter Koetsier ${ }^{1}$
}

\begin{abstract}
AвstRaCT.-The oriental weatherfish (Misgurnus anguillicaudatus) is invasive to 13 U.S. states and at least 9 other countries. Although this cryptic fish species is widespread, very little is known regarding its ecology. We used baited minnow traps to collect 237 individuals from water bodies connected to the Boise River, Idaho. To determine the diet of the fish within this invasive population, we dissected and examined stomach contents of the sampled fish. Most of the stomachs (158 of 237) were empty, and 42 contained only the trap bait. However, 37 contained natural food items. Gravimetric analysis, frequency of occurrence, and mean percent by number all indicated macroinvertebrates as the primary diet component, with chironomid larvae as the most numerous prey eaten. Graphical analysis of prey-specific abundance also indicated that oriental weatherfish fed on a generalized diet, of which detritus is likely an important part. An omnivorous diet may, in part, explain the species' ability to expand its invasive range quickly and successfully. Our findings add to a growing list of traits indicating that the oriental weatherfish fits the profile of a highly successful invader. As such, the oriental weatherfish should be a target species for further ecological research.
\end{abstract}

Resumen.-El Dojo (Misgurnus anguillicaudatus) es un pez invasor que se encuentra en 13 estados de los EE. UU., y por lo menos, nueve países más. Este enigmático pez tiene una distribución extensa, sin embargo se sabe poco sobre su ecología. Colectamos 237 ejemplares de cuerpos de agua conectados al Río Boise (Idaho, EE. UU.), utilizando foxinos como carnadas. Para poder determinar la dieta de los peces de esta población, disectamos y examinamos el contenido del estómago. La mayor parte de los estómagos (158 de 237) estaban vacíos, y 42 estómagos sólo contenían la carnada. Sin embargo, 37 contenían alimentos naturales obtenidos de su ambiente. El análisis gravimétrico, la frecuencia y el porcentaje promedio por número indicaron que los componentes principales de su alimentación eran macroinvertebrados, y que las presas más comunes eran las larvas de quironómidos. El análisis gráfico de la abundancia de presas también indicó que tienen una dieta generalista compuesta en gran medida por desperdicios. Se puede suponer que una dieta omnívora sea, en parte, la que permite a este pez extender su distribución de manera rápida y efectiva. Nuestros hallazgos indican que el dojo tiene el perfil de un pez con características efectivas de una especie invasora, y por lo tanto, debe ser objeto de más investigaciones ecológicas.

Globally, aquatic biodiversity is threatened by invasive species (Olden et al. 2004, Villeger et al. 2011). These new residents often disrupt existing community structure and may lead to loss of native biota (Mills et al. 1994, Dextrase and Mandrake 2006, Vitule et al. 2009). Most studies have focused on iconic invasive organisms, such as introduced sport fish (e.g., Townsend 1996) or species that have shown high economic impacts (e.g., zebra mussel, Dreissena polymorpha; Ricciardi 2003). However, many less charismatic species have been introduced, about which very little is known. The oriental weatherfish (Misgurnus anguillicaudatus) is one such invader.

The oriental weatherfish is native to eastern Asia, with a range spanning from India to Vietnam and north into southern Russia. Due in part to its popularity as an aquarium pet, the oriental weatherfish is now established in 10 countries outside of its native range including the Philippines, Turkmenistan, Italy, and Spain (Freyoff and Korte 2005, Simon et al. 2006, Franch et al. 2008), Germany (Meyer and Hinrichs 2000), and Australia (Keller and Lake 2007). Range expansion of the species appears to be ongoing, and most recently, wild populations have been described in the Netherlands (van Kessel et al. 2013) and Brazil (Abilhoa et al. 2013). Within North America, the species is established in Mexico (Contreras and Escalante 1984) and 13 of the United States (Fuller et al. 1999, Tabor et al. 2001, Ashton and Ciccotto 2010). In Idaho, the first reported oriental weatherfish was collected near the town of Eagle in 1951 (Courtenay et al. 1987). Since that time, a self-sustaining population has been thriving within irrigation

\footnotetext{
${ }^{1}$ Department of Biological Sciences, Boise State University, 1910 University Dr., Boise, ID 83725

${ }^{2}$ E-mail: alexurquhart@boisestate.edu
} 
canals and pond systems that have seasonal connection to the lower Boise River (Urquhart and Koetsier 2011).

Studies are lacking that examine the impacts of oriental weatherfish on native fish communities. However, potential threats have been identified in a few cases. In Australia, the species is banned from importation due to several concerns: decreased numbers of native fish where the oriental weatherfish has established (Burchmore et al. 1990, Arthington and Bludhorn 1995) and potential dietary overlap with native species (Lintermans 2002). The overlap includes competition with native species for invertebrate prey (Keller and Lake 2007) and direct predation of native fish eggs and larvae (Logan et al. 1996).

Currently, the invaded range of the oriental weatherfish includes disparate locations around the globe, and the species may adapt its diet to locally available food sources, a strategy employed by other invasive fishes (Harms and Turingan 2012, Kornis et al. 2012, Borcherding et al. 2013). Consequently, determination of diet is necessary to elucidate the ecological role-and the potential threats to native fishes-that the oriental weatherfish holds within each of its invaded regions. To this end, we conducted a dietary analysis of oriental weatherfish collected from canals and ponds connected to the Boise River in Idaho, USA.

\section{METHODS}

From May 2008 to July 2009, we collected oriental weatherfish from 6 water bodies seasonally connected to the Boise River (see Urquhart and Koetsier 2011 for collection sites, GPS coordinates, and voucher specimens). We placed minnow traps in suitable sites based on published habitat descriptions (Allen 1984, Tabor et al. 2001, Freyhof and Korte 2005) and Idaho Department of Fish and Game collection records (IDFG personnel, personal communication). Traps were approximately cylindrical, measuring $42 \mathrm{~cm}$ long and $22 \mathrm{~cm}$ wide, and made of vinyl-coated steel mesh (4-mm mesh size). Each end had a $2.5-\mathrm{cm}$ opening at the apex of an inward-facing cone. Each trap was baited with approximately $30 \mathrm{~g}$ of dry commercial dog food, submerged upon the substrate and marked with a small floating buoy. Traps were placed singly at each location and were moved or relocated based on site accessibility and seasonal dewatering. Water depth varied by location and ranged from $10 \mathrm{~cm}$ to approximately $1.5 \mathrm{~m}$.

We checked traps every 4-10 days, and captured oriental weatherfish were moved to the Boise State University, Aquatic Ecology Laboratory. A subsample of collected fish (237 individuals) were euthanized using a dilution of tricaine methanosulfonate (MS222) in freshwater. These fish were either dissected immediately or frozen at $-4{ }^{\circ} \mathrm{C}$ and later thawed for dissection. Dissected fish were sexed (Urquhart and Koetsier 2011), wet weighed (0.1 g), and measured for total length (TL). Each fish was incised from the vent forward through the pectoral girdle, and the alimentary canal was removed by excision at the vent and the foregut, just forward of the pectoral girdle. Heart, liver, and extraneous connective tissues were removed and discarded. Each complete digestive tract was preserved in $70 \%$ ethanol until examined for diet analysis.

We dissected each stomach and emptied the contents into a small glass bowl. Intestinal contents were not enumerated in this study because the advanced degree of digestion made identification impossible. Stomach contents were examined under a dissection scope at 10X-60X power (Zeiss Stemi 2000-C), and each item was classified as one of 3 broad categories: invertebrates, vegetation, or inorganic substrate. When possible, invertebrates were identified to order or family and then enumerated. Stomach content samples (separated into the 3 categories) were placed into aluminum pans and oven-dried for 24-48 h at $105{ }^{\circ} \mathrm{C}$ (Bowen 1996). From each dry-weight sample, we calculated percent composition by mass of each category per fish. Within the invertebrate category, we divided each sample into individual taxa and calculated frequency of occurrence based on the number of stomachs in which each was found. For these calculations, disarticulated pieces of unidentified arthropods were grouped together as a single category (hereafter called "disarticulated pieces") regardless of taxa or number of parts. We also included vegetation and inorganic substrate in calculations of frequency of occurrence.

To compare the relative abundance between individual food items, we calculated mean percent composition by number $\left(\% N_{i}\right)$ using the formula 
TABLE 1. Mass, frequency, and numerical composition of stomach contents of 37 oriental weatherfish collected from water bodies connected with the Boise River, Idaho. Frequency and abundance indicated that the fish were feeding primarily on macroinvertebrates and detritus.

\begin{tabular}{lccc}
\hline Food item & \% by mass & Frequency & $\begin{array}{c}\text { \% by number } \\
(\mathrm{SE})\end{array}$ \\
\hline INVERTEBRATES & 78.4 & & \\
Insecta & & & \\
$\quad$ Chironomidae & & 0.297 & $25.8(13.9)$ \\
$\quad$ Hemiptera & & 0.027 & $2.0(1.9)$ \\
$\quad$ Odonata & & 0.216 & $8.6(3.1)$ \\
$\quad$ Formicidae & & 0.027 & $6.0(6.1)$ \\
Disarticulated & & 0.405 & $13.2(3.8)$ \\
Crustacaea & & & \\
$\quad$ Daphnia & & 0.027 & $0.7(0.8)$ \\
$\quad$ Amphipoda & & 0.054 & $2.0(01.6)$ \\
Annelida & & & \\
$\quad$ Oligochaetae & & 0.027 & $0.7(0.7)$ \\
Mollusca & & & \\
$\quad$ Sphaeriidae & & 0.189 & $15.2(7.9)$ \\
$\quad$ Gastropoda & & 0.135 & $7.9(4.7)$ \\
VEGETATION & 14.6 & 0.243 & $12.6(5.5)$ \\
SUBSTRATE & 7.0 & 0.189 & $5.3(2.3)$ \\
\hline
\end{tabular}

$$
\% N_{i}=\frac{\sum_{j=1}^{n_{j}} N_{i j}}{\sum_{i=1}^{n_{i}} \sum_{j=1}^{n_{j}} N_{i j}},
$$

where $N_{i j}$ is the number of prey taxon $(i)$ in the stomach of a fish $(j), n_{i}$ is the number of prey taxa, and $n_{j}$ is the number of stomachs containing food. Standard error was calculated using the formula

$$
\mathrm{SE}_{\% N}=\frac{\sqrt{\frac{\sum_{j=1}^{n_{j}}\left(N_{i j}-N_{i} \sum_{i=1}^{n_{i}} N_{i j}\right)^{2}}{n_{j}\left(n_{j}-1\right)}}}{\frac{1}{n_{j}} \sum_{i=1}^{n_{i}} \sum_{j=1}^{n_{j}} N_{i j}},
$$

where variables are defined as above (Cochran 1977, as depicted in Tirasin and Jørgensen 1999). For these calculations, disarticulated arthropod pieces and soil components were assigned the value of a single organism regardless of the total amount found within a stomach. We also calculated prey-specific abundance $\left(P_{i}\right)$ using the formula

$$
P_{i}=\frac{\sum \mathrm{S}_{i}}{\sum \mathrm{S}_{t i}},
$$

where $S_{i}$ is the number of prey $i$ found in a given stomach and $S_{t i}$ is the total number of prey in a stomach which contained prey $i$.
Following Amundsen et al. (1996), we then plotted prey-specific abundance against frequency of occurrence to determine the feeding behavior and relative importance of each prey item. In this modification of Costello (1990), grouping of prey items along either axis or along the diagonal indicates the level of specialization or generalization of feeding within the population. Additionally, individual food items that are plotted farther toward the upper right of the graph indicate food specifically targeted by the fish (Amundsen et al. 1996).

\section{RESUlTS}

Dissected fish comprised 84 males, 149 females, and 4 juveniles. Body size ranged from $4.9 \mathrm{~cm}$ to $23.3 \mathrm{~cm}$ TL $(\bar{x}=13.8 \mathrm{~cm}, \mathrm{SE} 0.2)$ and from $0.6 \mathrm{~g}$ to $60.8 \mathrm{~g}$ wet weight $(\bar{x}=16.4$ $\mathrm{g}, \mathrm{SE}$ 0.7). Of the 237 dissected fish, 158 individuals had empty stomachs, and 42 individuals had stomachs containing only the trap bait. The bait was easily recognizable as a yellow, oily, non-cellular mass in the stomachs. The remaining 37 individuals comprised 18 males, 18 females, and 1 juvenile, ranging in length from $7.0 \mathrm{~cm}$ to $21.4 \mathrm{~cm}(\bar{x}=15.2 \mathrm{~cm}$, SE 0.5$)$, with wet weights from $2.0 \mathrm{~g}$ to $52.0 \mathrm{~g}(\bar{x}=$ $22.7 \mathrm{~g}, \mathrm{SE} 2.1$ ). Within the stomachs of these individuals, invertebrates made up $78.4 \%$ of ingested material by mass, followed by vegetation (14.6\%) and inorganic substrate (silt, sand, and very fine gravel, diameter $<3 \mathrm{~mm} ; 7.0 \%$ ). Frequency analysis showed that disarticulated pieces were present in $40.5 \%$ of the stomachs, followed (in frequency) by chironomid larvae $(29.7 \%)$, vegetation $(24.3 \%)$, odonate naiads and adults (21.6\%), and small freshwater clams (18.9\%). Additional contents consisted of snails, small crustaceans (amphipods and Daphnia), ants, a single small annelid worm, and aquatic hemipteran insects (Table 1). Vegetation was not identified to taxon because it primarily consisted of small ( $<3 \mathrm{~mm}$ in length) pieces of fibrous plant matter. Inorganic substrate was present in $18.9 \%$ of stomachs.

Chironomid larvae were present in the greatest abundance of any given prey item $(\bar{x}$ $=25 \%, \mathrm{SE} 13.9)$, followed in number by freshwater clams $(\bar{x}=15.2 \%$, SE 7.9$)$; however, no single food item was eaten in high relative abundance (Fig. 1). Plots of prey-specific abundance of individual food items showed 


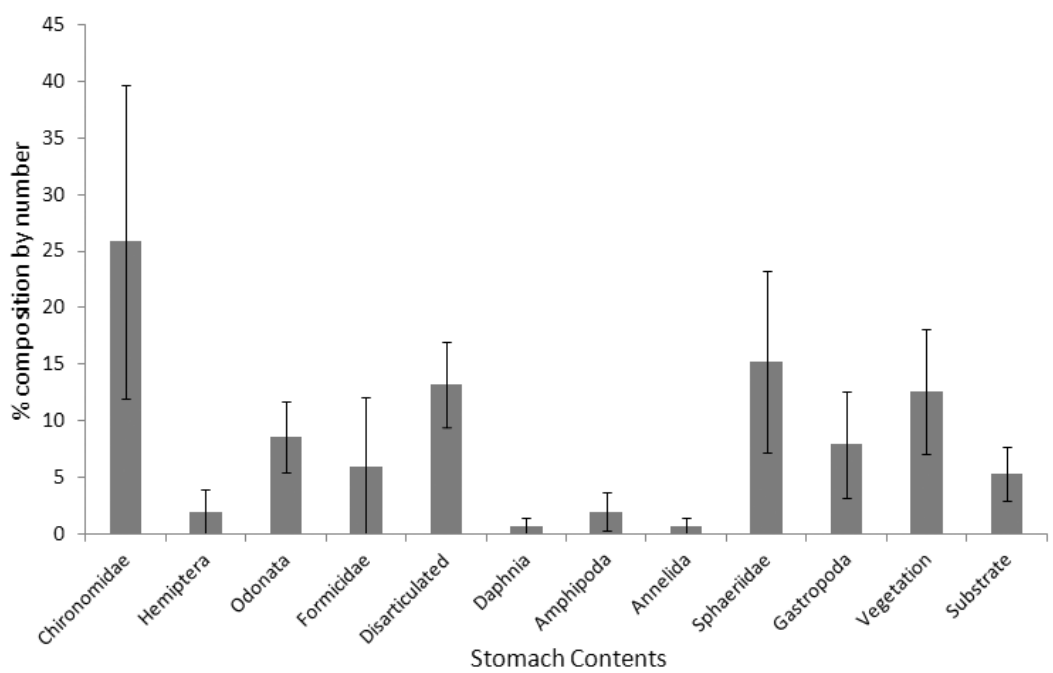

Fig. 1. Mean percent composition by number of stomach contents of 37 oriental weatherfish collected from water bodies connected with the Boise River, Idaho. Macroinvertebrates made up the majority of the food eaten, and chironomid larvae represented the most numerous prey item. Error bars represent standard error.

clustering along the diagonal, with most prey items located in the lower left quadrant when plotted against frequency of occurrence (Fig. 2).

\section{DISCUSSION}

Abundance and frequency analyses indicate that oriental weatherfish associated with the lower Boise River ate a diet consisting primarily of macroinvertebrates. Graphical analysis of prey-specific abundance (Fig. 2) corroborates this result and also indicates that the population, as a whole, fed on prey items of low relative importance (Costello 1990, Amundsen et al. 1996). In concordance with abundance and frequency data, chironomid larvae represented the invertebrate taxa most targeted by oriental weatherfish; however, the overall diet remained generalized.

The most abundant food items found were disarticulated pieces of invertebrates. Several of these parts contained soft tissue, suggesting that they were pieces of prey taken live by the fish (Keller and Lake 2007). Conversely, some of these disarticulated pieces appeared to be the molted exuviate of emerging insects. Detritus may therefore also be an important part of the oriental weatherfish's diet, and nutrients or important organic components (e.g., carbon, nitrogen) might be obtained through digestion of this material (Helfman et al. 2009). However, a small proportion of the stomachs also contained some inorganic substrate (sand, silt, small pebbles), suggesting that detritus, along with substrate materials, may have been accidentally ingested. Oriental weatherfish use their oral barbels to locate prey by tactile cues and chemoreception (Watanabe and Hidaka 1983). Once invertebrates are located, the fish suck them up from the substrate, possibly along with other benthic material. Thus, exuviate and substrate particles in the gut may be an unintended result of the species' feeding behavior rather than targeted dietary components.

Chironomid larvae were the second most frequent food and were eaten in the largest proportion. Most of these larvae were found intact and were easily identified by the attached head capsules, which probably indicate live prey consumption. Consequently, chironomids represented the most important individual prey item (Amundsen et al. 1996). However, we did not sample environmental abundance, so we could not determine whether oriental weatherfish preferred this prey or whether chironomids were simply the most abundant invertebrate in the habitat. This ambiguity reveals a disadvantage in using passive trapping methods to capture fish for analysis of gut contents. Oriental weatherfish are difficult to collect by electrofishing or active net seining due to their burrowing behaviors 


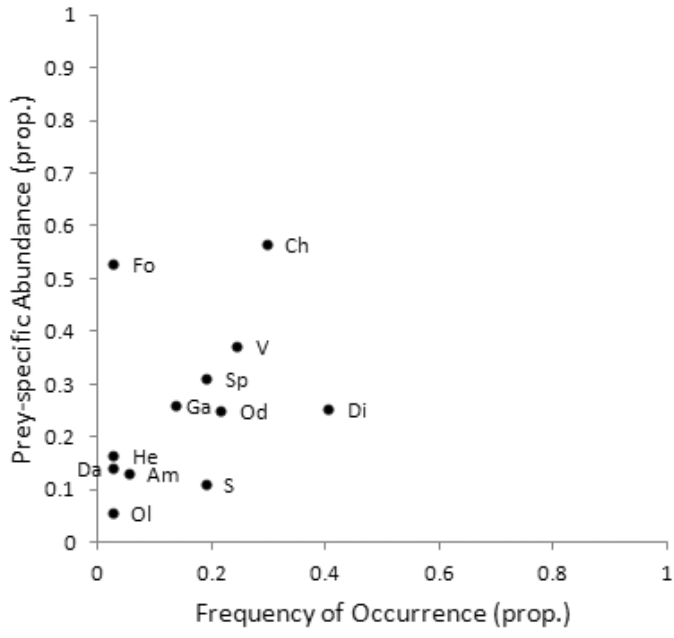

Fig. 2. Abundance and importance of food items from stomach contents of 37 oriental weatherfish collected from water bodies connected with the Boise River, Idaho, USA. Grouping of food items along the diagonal indicates a generalized diet shared by the population (Amundsen et al. 1996). All food identities are labeled to the right of their associated datapoint, except Daphnia, which is to the left (Ch-chironomid larvae, He-hemiptera, Od-odonata, Foformicidae, Di-disarticulated pieces, Da-Daphnia, Amamphipoda, Ol-oligochaeta, Sp-sphaeriidae, Ga-gastropoda, $\mathrm{V}$-vegetation, $\mathrm{S}$-inorganic substrate).

and their relative insensitivity to electrical current (Simon et al. 2006, Koetsier personal observation), hence our use of passive baited minnow traps in this study. However, fish entrapped for several days could feed opportunistically on nonpreferable food items along the bottom of the trap. Consequently, stomach contents may be a result of trap location rather than fish preference. Additionally, loss of easily digestible material during entrapment is also a concern (Bowen 1996). Although our analyses indicate a primarily invertebrate diet, other soft-bodied organisms, algal cells, phytoplankton, and other microscopic foods may have been digested while the fish were in the traps, leaving behind only the harder-to-digest invertebrate prey.

Within its native range, the oriental weatherfish is carnivorous when small, feeding mainly on zooplankton (Kubota 1961) and small benthic invertebrates such as emphermeropteran, trichopteran, and chironomid larvae (Katano et al. 2003). The species tends to undergo an ontogenic diet shift at approximately 10-13 cm TL, switching to an herbivorous diet (Kubota 1961). In our study, fish that contained natural food items ranged from $7.0 \mathrm{~cm}$ to $21.4 \mathrm{~cm} \mathrm{TL}$ $(\bar{x}=15.2 \mathrm{~cm})$ and fed primarily on invertebrates, with only 9 fish (range 9.4-21.4 cm TL, $\bar{x}=14.9 \mathrm{~cm})$ containing vegetation. These findings corroborate the few other existing reports on diet of invasive oriental weatherfish populations. In Australia (Burchmore et al. 1990, Keller and Lake 2007) and Washington State, USA (Tabor et al. 2001), benthic macroinvertebrates were the primary prey. However, none of these studies reported the specific sizes of fish that contained food in their stomachs, and neither did these studies explore the proposed ontogenic shift in diet. Our data is therefore the first to suggest that oriental weatherfish may have a longer carnivorous diet period (and at a larger size) within introduced habitats than is found in their native range. Thus, oriental weatherfish may be adapting to invaded habitats through delay of the characteristic diet shift seen within the species' native range. Though this interpretation must be tempered by our study's small sample size of fish that contained food ( 37 individuals), this information is nonetheless significant, as our sample size exceeds those in previous reports (5 fish-Burchmore et al. 1990; 7 fish-Tabor et al. 2001; 21 fish-Keller and Lake 2007).

As a relatively unknown but widespread invasive species, the oriental weatherfish may have unknown ecological effects on native fauna. Competition for important invertebrate prey may be a substantial factor where dietary overlap with native species exists. As a generalist omnivore, the oriental weatherfish may feed on prey that is important to native fishes. Under experimental conditions, oriental weatherfish caused significant decreases in invertebrate populations (Keller and Lake 2007), and the possibility of direct predation of native fish eggs and larvae has also caused concerns (Logan et al. 1996). Due to ongoing range expansion of the invasive oriental weatherfish, we predict that new populations will continue to be reported. As such, it is important to know the ecology of this secretive fish. We therefore suggest that further studies be conducted to elucidate the potential impacts on native fauna that are imposed by this cryptic but widespread invader.

\section{ACKNOWLEDGMENTS}

We thank D. Daw and J. Tabbutt for their assistance in the field and laboratory. We also 
thank Idaho Department of Fish and Game personnel at the Eagle Island Hatchery and the Southwest Regional and Research Offices for methodology, insights, and access to collection locations. Most importantly, we thank Dr. James Long, Professor Emeritus of Boise State University, for introducing us to this novel fish species. All field and laboratory procedures were carried out in compliance with the American Fisheries Society's Guidelines for the Use of Fishes in Research (UFR 2004).

\section{Literature Cited}

Abilhoa, V., H. Bornatowski, and J.R.S. Vitule. 2013. Occurrence of the alien invasive loach Misgurnus anguillicaudatus in the Iguaçu River basin in southern Brazil: a note of concern. Journal of Applied Ichthyology 29:257-259.

Allen, S. 1984. Occurrence of juvenile weatherfish Misgurnus anguillicaudatus (Pisces: Cobitidae) in the Yarra River. Victorian Naturalist 101:240-242.

Amundsen, P.-A., H.-M. Gabler, and F.J. Staldvik. 1996. A new approach to graphical analysis of feeding strategy from stomach contents data-modification of the Costello (1990) method. Journal of Fish Biology 48:607-614.

Arthington, A.H., AND D.R. BLudhorn. 1995. Improved management of exotic aquatic fauna: research and development for Australian rivers. Land and Water Resources Research and Development Corporation, Canberra, Australian Capital Territory.

Ashton, M., And P. Ciccotto. 2010. First records of oriental weatherfish (Misgurnus anguillicaudatus) in Maryland. Northeastern Naturalist 17:671-672.

Borcherding, J., M. Dolina, L. Heermann, P. Knutzen, S. Krüger, R. van Treeck, and S. Gertzen. 2013. Feeding and niche differentiation in three invasive gobies in the Lower Rhine, Germany. Limnologica 43:49-58.

Bowen, S.A. 1996. Quantitative description of diet. Pages 513-532 in B.R. Murphy and D.W. Willis, editors, Fisheries Techniques. American Fisheries Society, Bethesda, MD.

Burchmore, J., R. Faragher, and C. Thorncraft. 1990. Occurence of the introduced oriental weatherloach (Misgurnus anguillicaudatus) in the Wingecarribee River, New South Wales. Pages 38-46 in D.A. Pollard, editor, Introduced and translocated fishes and their ecological effects. Australian Government Publishing Services, Canberra, Australian Capital Territory.

Cochran, W.G. 1977. Sampling techniques. 3rd edition. John Wiley \& Sons, New York, NY.

Contreras, S.B., and M.A. Escalante. 1984. Distribution and known impacts of exotic fishes in Mexico. Pages 102-130 in W.R. Courtenay and J.R. Stauffer, editors, Distribution, biology, and management of exotic fishes. Johns Hopkins University Press, Baltimore, MD.

Costello, M.J. 1990. Predator feeding strategy and prey importance: a new graphical analysis. Journal of Fish Biology 36:261-263.

Courtenay, W.R., C.R. Robins, R.M. Bailey, and J.E. DEACON. 1987. Records of exotic fishes from Idaho and Wyoming. Great Basin Naturalist 47:523-526.
Dextrase, A.J., And N.E. Mandrake. 2006. Impacts of alien invasive species on freshwater fauna at risk in Canada. Biological Invasions 8:13-24.

Franch, N., M. Clavero, M. Garrido, N. Gaya, V. LóPEZ, Q. Pou-Rovira, And J.M. Queral. 2008. On the establishment and range expansion of oriental weatherfish (Misgurnus anguillicaudatus) in NE Iberian Peninsula. Biological Invasions 10:1327-1331.

Freyhof, J., AND E. Korte. 2005. The first record of Misgurnus anguillicaudatus in Germany. Journal of Fish Biology 66:568-571.

Fuller, P.L., L.G. NiCO, AND J.D. Williams. 1999. Nonindigenous fishes introduced into inland waters of the United States. American Fisheries Society, Bethesda, MD.

Harms, C.A., And R.G. Turingan. 2012. Dietary flexibility despite behavioral stereotypy contributes to successful invasion of the pike killifish, Belonesox belizanus in Florida, USA. Aquatic Invasions 7:547-553.

Helfman, G.S., B.B. Collette, D.E. Facey, and B.W. BowEn. 2009. The diversity of fishes: biology, evolution, and ecology. 2nd edition. Blackwell, Chichester, United Kingdom; Hoboken, NJ.

Katano, O., K. Hosoya, K. Iguchi, M. Yamaguchi, Y. AONuma, AND S. KitAnO. 2003. Species diversity and abundance of freshwater fishes in irrigation ditches around rice fields. Environmental Biology of Fishes 66:107-121

Keller, R.P., and P.S. LaKe. 2007. Potential impacts of a recent and rapidly spreading coloniser of Australian freshwaters: oriental weatherloach (Misgurnus anguillicaudatus). Ecology of Freshwater Fish 16:124-132.

Kornis, M.S., M.L. Mercado-Silva, and M.J. Vander ZANDEN. 2012. Twenty years of invasion: a review of round goby Neogobius melanostomus biology, spread and ecological implications. Journal of Fish Biology $80: 235-285$.

Kubota, Z. 1961. Ecology of the Japanese loach, Misgurnus anguillicaudatus (Cantor). Journal of the Shimonoseki College of Fisheries 11:141-338.

Lintermans, M. 2002. Fish in the upper Murrumbidgee catchment: a review of current knowledge. Environment ACT, Canberra, Australian Capital Territory.

Logan, D.J., E.L. Bibles, AND D.F. MarkLE. 1996. Recent collections of exotic aquarium fishes in the freshwaters of Oregon and thermal tolerance of oriental weatherfish and pirapatinga. California Fish and Game 82:66-80.

Meyer, L., AND D. Hinrichs. 2000. Microhabitat preferences and movements of the weatherfish, Misgurnus fossilis, in a drainage channel. Environmental Biology of Fishes 58:297-306.

Mills, E.L., J.H. Leach, J.T. Carlton, and C.L. Secor. 1994. Exotic species and the integrity of the Great Lakes. BioScience 44:666-676.

Olden, J.D., N.L. Poff, M.R. Douglas, M.E. Douglas, AND K.D. FAUSCH. 2004. Ecological and evolutionary consequences of biotic homogenization. Trends in Ecology and Evolution 19:18-24

Ricciardi, A. 2003. Predicting the impacts of an introduced species from its invasion history: an empirical approach applied to zebra mussel invasions. Freshwater Biology 48:972-981.

Simon, T.P., G. BRight, F. Veraldi, J.R. Smith, and J.R. STAHL. 2006. New records for the alien oriental weatherfish, Misgurnus anguillicaudatus, in the Lake 
Michigan basin, Indiana (Cypriniformes: Cobitidae). Proceedings of the Indiana Academy of Science 115: 32-36.

Tabor, R.A., E. Warner, and S. Hager. 2001. An oriental weatherfish (Misgurnus anguillicaudatus) population established in Washington State. Northwest Science 75:72-76.

Tirasin, E.M., AND T. Jørgensen. 1999. An evaluation of the precision of diet description. Marine Ecology Progress Series 182:243-252.

Townsend, C.R. 1996. Invasion biology and ecological impacts of brown trout Salmo trutta in New Zealand. Biological Conservation 78:13-22.

Urquhart, A.N., AND P. Koetsier. 2011. Pectoral fin morphology as a reliable field sexing characteristic in populations of the invasive oriental weatherfish (Misgurnus anguillicaudatus). Copeia 2011:296-300.

[UFR] Use of Fishes in Research Committee. 2004. Guidelines for the use of fishes in research. American Fisheries Society, Bethesda, MD. van Kessel, N., M. Dorenbosch, B. Crombaghs, B. Niemeijer, AND E. BinnendijK. 2013. First record of Asian weather loach Misgurnus anguillicaudatus (Cantor, 1842) in the River Meuse basin. BioInvasions Records 2:167-171.

Villeger, S., S. Blanchet, O. Beauchard, T. OberDORFF, AND S. BROSSE. 2011. Homogenization patterns of the world's freshwater fish faunas. Proceedings of the National Academy of Sciences of the United States of America 108:18003-18008.

Vitule, J.R.S., C.A. Freire, and D. Simberloff. 2009. Introduction of non-native freshwater fish can certainly be bad. Fish and Fisheries 10:98-108.

Watanabe, K., and T. Hidaka. 1983. Feeding behaviour of the Japanese loach, Misgurnus anguillicaudatus (Cobitididae). Journal of Ethology 1:86-90.

Received 4 April 2013 Accepted 6 November 2013 